\title{
Fallacies of hope: Contesting narratives of abolition in Turner's Slave Ship
}

\section{Laura Brace*}

School of History, Politics and International Relations, University of Leicester, Leicester, UK

\section{Abstract}

This article explores the risks and dangers of redemptive readings of JMW Turner's (in)famous 1840 painting, Slave Ship (Slavers Throwing Overboard the Dead and DyingTyphon Coming on) that assume that we cannot be complicit in anything other than abolition and deliberately forget and disavow the underlying structures and continuing dispossessions of slave racial capitalism. How should we mobilize the underlying politics of the painting? What is at stake for us in how we interpret it? The paper reads the painting as an intervention in an important set of nineteenth-century debates around slavery and the slave trade, and as a key element in the war of representation over slavery that has raged ever since. How should we respond to the suffering of the slaves in the foreground of the picture, and to the patch of blue sky in the background? The question, and the painting, call on us to think carefully about the relationship between the pasts and presents of slavery. How should we incorporate black death and white abolitionism into our stories, self-understandings and conceptions of justice? As this paper will argue, Turner's painting brings us all into a space of temporal entanglement, and leaves us to question the history of modernity and the meaning of freedom both in the past and in the present. It is a picture of the tensions of empire, painted at the beginning of a new phase of imperialism that extended the reach Britain's geographical and moral boundaries, and carried both slavery and abolition within it. The paper argues that the

\footnotetext{
*E-mail: 1b21@1e.ac.uk
} 
painting shows us the uncomfortable relationship between abolitionism and imperialism and that we can use it to help us build new, and more politicized, understandings of the pasts and presents of racial slavery, its legacies and its multiple dimensions.

Keywords: Turner; slave ship; the Zong; abolitionism; representations of slavery; imperialism; slave trade; jettison; temporal entanglement 10 keywords allowed. Add 5 more for the search engines? Optional

\section{Introduction}

This article explores Turner's painting of the Slave Ship, its relationship to the Zong massacre of 1781, and its reception history, Turner's own connections to slavery and his depiction of drowning black bodies. It traces the shift from the distaste and laughter that greeted the first showing of the painting to its co-option into the redemptive narrative of abolition, and explores the risks and dangers of a redemptive reading of the painting that assumes that we cannot be complicit in anything other than abolition and deliberately forgets and disavows the underlying structures and continuing dispossessions of slave racial capitalism. How should we mobilize the underlying politics of the painting? What is at stake for us in how we interpret it?

This article reads the painting as an intervention in an important set of debates around slavery and the slave trade, and as a key element in the 'multi-theatre conflict' of the war of representation over slavery. ${ }^{1}$ How should we respond to the drowning slaves in the foreground of the picture, and to the patch of blue sky in the background? The question is a highly political one that requires us to think carefully about the relationship between the pasts and presents of slavery, and about how we should incorporate both black death and white abolitionism into our stories, self-understandings and conceptions of justice. As this paper 
will argue, Turner's painting brings us all into a space of temporal entanglement, and leaves us to question the history of modernity and the meaning of freedom both in the past and in the present. It is a picture of the tensions of empire, painted at the beginning of a new phase of imperialism that extended the reach Britain's geographical and moral boundaries, and carried both slavery and abolition within it. In the painting we can see slave and free labour economies intertwined, and "the backwardness of slavery inside the forwardness of modernity." ${ }^{2}$ If we read it as a painting of the uncomfortable relationship between abolitionism and imperialism, and resist the "interpretive closure and conflation" of insisting that is a painting of past and righted wrongs, we can move towards new, and more politicized, understandings of the pasts and presents of racial slavery, its legacies and its multiple dimensions. ${ }^{3}$

\section{The story of the Zong}

Turner's painting Slave Ship (Slavers Throwing Overboard the Dead and Dying - Typhon Coming on), first displayed at the Royal Academy in 1840, is usually interpreted by modern commentators as a depiction of a massacre on board the slave ship Zong in 1781. I want to begin by returning to the story of the Zong as a traumatic text, and as an origin story for the abolition movement. The insurance case of the slave ship Zong came to court in 1783. A Dutch ship owned by a Liverpool consortium set sail from St Thomas on the West Coast of Africa to Jamaica with 470 African slaves on board and a crew of 17 . The ratio of crew to slaves was 1:26, grossly inadequate even for the slave trade. Under the Slave Trade Regulation Act, better known as Dolben Act (not passed until 1788), the Zong would have been allowed to carry 175 slaves. $^{4}$

The Zong left Africa on 6 September 1781 and in November the ship steered the wrong way. They sighted Jamaica, but misidentified it as Saint-Domingue and continued 
westward, leaving Jamaica behind. ${ }^{5}$ In the end, it took them 100 days to make the 61-day journey to Jamaica. Captain Luke Collingwood (a ship's surgeon, acting as Captain for the first time) found himself in charge of a ship low on supplies and water, with many dangerously ill slaves on board. More than 60 enslaved captives died from viral dysentery, and up to twice that number were probably seriously ill and in need of large amounts of water. These sickly and contaminated captives represented a danger to the lives of the crew and to the commercial viability of the enterprise. Collingwood's response was to jettison the ship's sick prisoners. Over the course of three days, the captain, the mate and several others selected 132 of the weakest and most ailing slaves to throw overboard, 54 on the first day, 42 on the second and a further 26 over the next three days. Of the final 26, the first 16 submitted to be thrown into the sea, "but the rest with a noble resolution would not suffer the officers to touch them, but leaped after their companions and shared their fate." ${ }^{6}$ In court, counsel for the Zong's owners argued that the slaves had to be killed in order to save the lives of the remaining captives and the ship's crew, and that the captain had no choice but to throw them overboard. The suspicion was that Collingwood was hoping to cash in on the insurance by not losing money on slaves who would have died of natural causes and the lack of drinking water. The legal argument was over whether the jettisoning of 133 living, breathing Africans could be deemed an act of absolute necessity. ${ }^{7}$

A master of a ship in distress was, with the advice and consent of his officers and sailors, entitled to throw goods overboard, to lighten the vessel, for the preservation of the whole. Losses undertaken to save a ship, such as jettisoning or cutting down the masts in a storm, represented a risk that would be shared among those investing in the voyage. The risk was distributed between all the investors, so that whoever incurred the cost, whether it was the owner of the ship whose mast was cut or the merchant whose goods were jettisoned, would be compensated by the others. Jettisoning was legally defined as an act of sacrifice 
when the ship was under immediate threat, and no one person was held directly liable. ${ }^{8}$ The Solicitor General, John Lee, argued that the Zong was just such an act of sacrifice. For the purposes of insurance, the slaves were classed as goods and property, as articles of trade. Lord Mansfield, the presiding Judge in the proceedings, made clear that, in law, it made no difference whether the cargo thrown overboard was a consignment of slaves or of horses. ${ }^{9}$ It was, he pointed out, commercial practice in insurance contracts to treat slaves exactly like horses. ${ }^{10}$ They were "animate chattel," and the only relevant legal question was whether they had been thrown overboard because they posed an immediate threat to the survival of the rest of the cargo or of the crew.

Olaudah Equiano brought the case to Granville Sharp's attention and urged him to take it up. Sharp wrote up an account of the court proceedings and the case was widely publicized. He described how Collingwood picked out the slaves and ordered the crew to throw them into the sea with their hands fettered or bound, over three days, even after the rain had replenished their water supplies. 133 people "were wilfully put to violent death," not through fear of insurrection, but on a pretended plea of necessity. ${ }^{11}$ Sharp's immediate aim was to bring murder charges against the captain and crew. Those who argued that they should not be tried for murder were treating "the destruction of living men" as if it were merely a case of jettisoning chattels or goods for the purposes of insurance, forgetting the nature of these goods, "yet that still are men; that their existence in human nature, and their actual rights as men, nay, as brethren, still remain!"12

It was shameful that the property others held in them was being favoured over their right to life. Sharp spelled it out: the property of "these poor injured Negroes in their own lives, notwithstanding their unhappy state of slavery, was infinitely superior, and more to be favoured, in law, than the slave-holders' or slave-dealers' iniquitous claim of property in their 
persons." 13 The natural right to life ought not to be suppressed in favour of a "mere pecuniary claim in the most doubtful species of property, the service of Slaves." 14

Sharp's account of the massacre insisted that what happened on board the Zong was a flagrant offence against God and humanity that ought to be scrutinized, judged and punished. Evil could not be justified by necessity. ${ }^{15} \mathrm{He}$ collected all the information that he could "concerning this horrible transaction" for the sake of national justice, so that "the blood of the murdered may not rest on the whole kingdom," which was already labouring under a load of guilt for tolerating the slave trade. ${ }^{16}$ Thomas Clarkson described events on board the Zong as an "atrocious and unparalleled act of wickedness" that would live on in the memory because hundreds would say "that they heard the melancholy evidence with tears." 17 The abolitionists had scented a cause that they could make work for them. Sharp was in court throughout the trial with a short hand writer to take down the facts. He then gave the story of the trial to the public, to the Lords of the Admiralty "as the guardians of justice upon the seas," and to the Duke of Portland as the principal minister of state. They took no notice, but they could no longer claim ignorance. Their lack of concern fed into an abolitionist narrative about the power of the public, and the transformative power of witnessing.

The publication of Sharp's account of the trial in the newspapers "made such an impression upon others, that new coadjutors rose up" and found themselves sewn into a chain of events that culminated in abolition. ${ }^{18}$ The story of the massacre on board the Zong was told and retold until it became what Anita Rupprecht calls "the exemplary narrative for abolitionist sentiment." ${ }^{19}$ In the process, the complexities of the story were lost. The focus shifted to the individual brutality and inhumanity of Captain Collingwood and the mass murder committed on a British ship by British sailors. It became much harder to see the ways in which the emerging system of finance capital meant that slaves were treated as human collateral, almost as a species of money, so that a drowned slave functioned as a "still 
existent, guaranteed, and exchangeable form of currency" in insurance practice and in court. $^{20}$

In the telling and retelling of the case, Sharp and others demanded that readers encountered and re-encountered the details, reliving the shock, the horror and the violent impression on the mind. Baucom argues that Sharp's "traumatic text" focused on the loss of life, and insisted on "listening to the voice speaking from the wound of this loss over and over and over again." 21 The effect was to preserve the singularity of the massacre, to focus on "murder as a form of fiscal transaction." 22 Relating to the events on board on the Zong as a trauma and an unparalleled act of wickedness is a way of privatising and containing our responses, turning our focus in on the suffering of individuals and our own sentimental reactions. We hear the melancholy evidence with tears, but the role of capital and its practices are occluded from the underlying structure of feeling. Rupprecht argues that what happened on board the Zong ended up "congealed into a generalised story of ineffable loss, passive victimhood and redemptive tragedy." It became part of a "long, dominant discourse of humanitarian triumph." 23

If Turner's painting is interpreted as a representation of the Zong, then when we stand in front of it we are confronted by a painting of ineffable loss and trauma, but as spectators we are given a way out through the narrative of humanitarian triumph and the moral certainties of abolition. This fits with critical readings of violence in painting as inviting a specific range of affective responses from the viewer, giving us "a highly individual yet shareable vision of the world," and showing us moments of inescapable terror in ways that bring the present and the disjunctive past together. ${ }^{24}$ As Baucom argues, the ship is removed from the present, and the painting becomes a picture not of the Zong and its atrocities, of what actually happened, but of "an idea exchanged between the artist and the spectator." 25 For Baucom, the painting makes visible the sentimental mind of romantic liberalism, offering 
the possibility of knowing the truth of the world without knowing the melancholy facts of history. ${ }^{26}$ As Sherene Razack argues in a different context, the details are unnecessary in this simpler story of good and evil, and the absence of these details is the precondition of deliberate forgetting. ${ }^{27} \mathrm{We}$ are positioned as the impartial and sympathetic spectator "who looks and then moves on." ${ }^{28}$ We contemplate our own thoughts and feelings, and those of the artist, and then pass on to the next painting. The erasure of the slaves themselves, their reduction to passive victimhood, "signals our investment in understanding ourselves outside of history" which allows us to become the humanitarians and the abolitionists that we say we are, both in the nineteenth and the twenty-first centuries. ${ }^{29}$ On this interpretation, the politics of the painting cement the history of abolition as a story to be proud of, and allow slavery to become merely a historical relic, epitomised by a single and singular traumatic event and then pushed into the background.

\section{Turner's painting of the Slave Ship}

This means that Turner's painting can tell us a great deal about how terrible and traumatic events such as this atrocity come to be appropriated and owned by later generations, and what kind of a property it is that we hold in slavery's past. These are highly political questions about power and representation that were live and contested in the 1840 context. Turner's painting Slave Ship was exhibited at the Royal Academy in 1840, coinciding with the inaugural meeting of the Anti-Slavery Convention in Freemason's Hall, commemorated by another, very different, painting by Benjamin Robert Haydon. ${ }^{30}$ The received wisdom, that I am contesting here, seems to be that Turner was inspired by reading Thomas Clarkson's record of the Zong events in his History of the Rise, Progress and Accomplishment of the Abolition of the African Slave-Trade first published in 1808 and reprinted in 1839, and wanted to produce a painting that was both about the slave trade and its abolition. ${ }^{31}$ 
For Albert Boime, the painting is "the cultural encoding of one strain of evangelical Toryism," articulating how the human experience is debased by the cash nexus. ${ }^{32}$ Jack Lindsay reads the painting in the same way, as a reaction to the social crisis in 1840 and 1841 and the rise of the society of the cash nexus "which in its blindness cannot see the disaster it is bringing on itself." ${ }^{33}$ Both radicals and conservatives in 1840 lamented the deadening reach of laissez faire capitalism and joined in shared protest against the consequences of economic and social liberalism. Boime and Lindsay both point to lines of verse by Turner from an unfinished poem "Fallacies of Hope" which were exhibited alongside the painting:

Aloft all hands, strike the top-masts and belay;

Yon angry setting sun and fierce-edged clouds

Declare the Typhon's coming.

Before it sweep your decks, throw overboard

The dead and dying - ne'er heed their chains

Hope, Hope, fallacious Hope!

Where is thy market now?

The word on alludes to the section of James Thomson's poem Summer (1727), part of his 1730 suite of poems, The Seasons, where the "typhon" is one of the terrors of the tropics along with the "direful shark" that preys on the crew and human cargo of the slave ships. Typhon is a Greek mythological figure, a terrible monster brought forth by Mother Earth, with a hundred dragon heads who could tear up mountains. He was cast into the underworld by Zeus, and pinned underneath Mount Etna where he continued to belch out lava and smoke and to be the source of violent and destructive winds. ${ }^{34}$ For Boime, the painting is part of Turner's examination of the impact of industrialisation, "the grooved, briny path, with its 
sinking bodies" echoes the new assembly lines of the factories and the underground tunnels of the mines. On Boime's reading, in attacking the slave trade, Turner was attacking an institution that was diminishing in importance for the British economy rather than pointing out the abuses still being perpetrated in the West Indian colonies. ${ }^{35}$ In other words, the Slave Ship is a depoliticized work of art, an evasion, a reduction of the tragedy to melodrama. Boime's argument is that Turner neutralised the content of his painting by aestheticizing it, and by focusing on the Zong as an event that was comfortably in the past he tried to take the slave system outside both time and place and treat it as an example of the inhumanity of commerce. ${ }^{36}$ For some subsequent writers, this choice of a retrospective subject was crucial, allowing Turner to evade the realities of post-Emancipation and perpetuate an image of black people as passive suffering victims. ${ }^{37}$

As Mark Frost points out, these arguments about depoliticization and evasion are difficult to make in the context of 1840.1840 was an important year for the global antislavery movement, and "Turner was responding to horrors that were not past, but continuing, and not British, but global." 38 John McCoubrey pushes further on this. The campaign to abolish the international slave trade was at its peak in 1840, he argues, and the wrecking of slave ships by storm was a common metaphor for an end to the slave trade by divine intervention. In his view, the Slave Ship relates to romanticism and abolition through sunset and shipwreck, and, just as importantly, through the intensification of the traffic in slaves after the abolition acts of $1838 .^{39}$

Britain was centrally involved in the enforcement of abolition, and the Navy chased slave ships from Portugal, Spain and South America to try and shut down the trade that was competing against their labour system. In this sense, the picture is a deeply political painting of the tensions of empire, working out what British values meant in this new global context within which African states were regarded as unworthy of the protection of international law 
because they lacked the civilized credentials of modern states. The British suppression of the slave trade was carried out through the coercion and intimidation of other states in breach of the law of nations. It was a unilateral and inherently imperialist decision, for example, to arrest suspected slave ships belonging to Portugal in Brazilian waters. The Slave Trade (Portugal) Act of 1839 authorised British warships to detain Portuguese vessels equipped for the slave trade and the Vice-Admiralty courts in Freetown, Sierra Leone and later in St Helena condemned them. This empowered the Navy to patrol and make captures south of the equator. ${ }^{40}$ Robin Law points to the growing arrogance of British maritime power from the end of the eighteenth century, denying territorial rights in local waters and treating the sea as a "domain which is everywhere ours." 41

McCoubrey argues that we need to look again at the painting in the context of this intensification of the slave trade and the campaign for universal abolition. The Transatlantic Slave Trade Database tells us that approximately 2,793,133 people were loaded on to slave ships from 1808 onwards, so that more than a quarter of all the Africans subjected to the Middle Passage sailed after the British abolition of the slave trade in $1807 .{ }^{42}$ After abolition, until the 1850s, ships were smaller and designed to be lighter and faster to avoid detection and to escape effectively, and slavers crammed even more people aboard, shackled more heavily to try and prevent insurrection. ${ }^{43}$ The technologies of transportation were changing on both sides of the slave trade. The Waterwitch, for example, was built as a racing yacht, an experimental, fast-sailing vessel able to power into a head sea, faster than the clipping schooners used in the slave trade. It was bought by the Admiralty as a man-of-war and became "an icon of the West Africa squadron." 44

Royal Navy patrols were under orders to seize slave ships as prizes and liberate the slaves on board, but naval suppression was proving to be far more difficult than the abolitionists had expected. ${ }^{45}$ Many of the abolitionists, including Clarkson and Thomas 
Fowell Buxton, were equivocal about the anti-slave-trade squadrons. There was a strong sense, drawn from the eye-witness evidence of naval officers, surgeons, chaplains and passengers that conditions on board the slave ships worsened during the nineteenth century, "as the once open trade became clandestine, and ever more speculative." 46 A so-called prize crew would take command of the slave ship to take it to the nearest designated port where they could establish at court the legality of the capture. Most prizes were adjudicated at Freetown in Sierra Leone, far away from the main slaving ports in the Bights of Benin and Biafra, and the captured ships were often sailed along the coastline, in poor condition, with the captive Africans exposed on deck. A lack of experience and a lack of navigational gear often extended the length of the voyage. The ship captains were paid head money on the basis of the number of slaves set free. Once legal capture was confirmed, bounties were paid and the ship was either condemned or resold. As Emma Christopher points out, "what had been run as an above-board, legitimate section of big business had to become more covert and furtive, and risks and profits became higher as the stakes were raised." 47 This meant that when pursued, slavers often threw their cargo of living humans overboard to lighten the ships for greater speed, starting with the sick and dying and then "eventually, if capture appeared imminent, the whole cargo to destroy evidence of their guilt." ${ }^{48}$ The 1827 parliamentary enquiry into the suppression of the slave trade concluded that "double suffering" awaited the unfortunate slave who "captured by a cruiser, feels the iron grasp of the misdirected philanthropy of Britain."49

By 1840 , there had been many stories of cornered slave ships ditching large numbers of Africans over the side. In 1831 the Times reported that two Spanish ships, the Rapido and the Regulo, were trapped by the Royal Navy and disposed of between 125 and 180 people in this way. Captain Ramsey of the cruiser Black Joke, sent two tenders to chase the Spanish ships, and during the chase they were seen "to throw their slaves overboard, by twos, 
shackled together by the ankles, and left in this manner to sink or swim." ${ }^{50}$ In 1838 , with a smallpox epidemic on board, the Leão heading from Mozambique to Brazil threw thirty infected captives overboard. ${ }^{51}$ The abolitionists accused the Royal Navy of causing, or at least exacerbating, these crimes as squadrons waited for ships to be fully loaded before giving chase in order to maximise the potential head money. Henry Brougham spoke in Parliament in 1838 , claiming that the current system needed to be changed to reward men for preventing a slaver's voyage, not for interrupting it. McCoubrey claims that Turner "could hardly have failed to read this speech in preparation for this controversial project." 52

Brougham's speech was published in pamphlet form and widely distributed, and there was a general sense of jettison and pursuit as publicly linked, and as part of a wider discussion of the intensification and expansion of the slave trade in the nineteenth century. ${ }^{53}$ Turner can be read as joining the critics of the government's policy, questioning the probity of the naval officers, and so as painting a highly political picture of the present, rather than reflecting on a distant past. If McCoubrey is right, then the painting is rooted in the concrete horror of the slave system at a particular time and place, and Turner was producing a space and its meanings. ${ }^{54}$ McCoubrey identifies the slaver as flying the flag of the merchant ship of Buenos Aires that could be a flag of convenience for a Spanish or a Portuguese slaver, and it has the rigging of a polacre, merchant vessels used in the Mediterranean. Polacres have three simple pole-masts, light rigging and rope ladders and were used by the Spanish in the slave trade. The dogs swimming in the right hand corner are, McCoubrey points out, spaniels, Spanish dogs, which may be "a Turnerian pun." 55 The Zong murders, he concludes, "took place on a ship in dead calm and could not have been a visual source for Turner's painting." ${ }^{\text {"56 }}$ Jettison, on the other hand, was a live, stormy political issue in 1840 , not a question that was safely sealed off in the past. 


\section{The reception of Slave Ship: The sea of blood}

The reception history of the painting tells us a great deal about Turner's project to integrate history and landscape, and about the reactions of his viewers to his attempt to depict the horror and the guilt of the slave trade. Turner's painting was first publicly displayed at the Royal Academy Exhibition in 1840 where it met with ridicule for its marigold sky, pomegranate sea and pink and green fish that looked like garden flowers. ${ }^{57}$ Most of the critics found it either difficult or impossible to reconcile the horrific content and the political message being presented as a seascape and a sunset. Thackeray, writing a review for Fraser's Magazine asked "Is the picture sublime or ridiculous?" and answered himself, "Indeed I don't know which." The more hostile reviews in Tory publications focused on the leg in the foreground of the picture: "Of all the birds in the air, and all the fishes in the sea, what have we in the foreground? It is a black leg thrown overboard, and round it runs fish great and small." The review goes on to say, "The fish claiming their legacy is very funny," and as Marcus Wood points out, the leg was treated as a site of facetious humour by the first critics. Ruskin described how children giggled at the leg when they were shown the picture, and he found it difficult to defend it because it is badly drawn, bloated and thick. Contemporary critics, like the children, "could not see beyond the leg, and also responded to it by laughing" at its image of a human being falling, diving and upended. ${ }^{58}$ As Boime says, the reception of the picture "betrayed an uncomfortable mixture of nervousness and sardonic humour," as well as some "visceral distaste." 59 The leg is clearly female, and morally transgressive, like a female dancer's in an age when ballet was "a spectacle of erotic interest, since it was the single public occasion where female legs were visibly exposed." ${ }^{60}$ It was more than that though. The painting is not so much of a woman as of incomplete body fragments, not existing in human nature, "the reduction of the human body to detritus," turned into food for fish. ${ }^{61}$ 
In many ways, the painting was made famous not by Turner, but by John Ruskin. As Hillary Gravendyk says, the painting circulated not as an image, but as Ruskin's vivid description and his imaginative act of narration. The canvas has, she argues "been metaphorically emptied out and repopulated with a commentary about it" until Ruskin's description has become a virtual surrogate for the painting. ${ }^{62}$ Ruskin's reading of the painting was "deeply sympathetic," but the commentary has also become infamous for mentioning the drowning slaves only in passing. ${ }^{63}$ As Frost points out, Ruskin had an intense relationship with the Slave Ship. ${ }^{64}$ His father bought it in 1843 for 250 guineas and gave to his son as a New Year's present in $1844 .{ }^{65}$ Ruskin lived with the painting (in his bedroom and then in the corridor) until 1872 when he sold it to an American collector, saying that it had become too uncomfortable and painful to live with: "I part with the picture because as I grow old, I grow sad, and cannot endure anything near me, either melancholy or violently passionate." 66 Ruskin's discussion of the painting in his book Modern Painters Vol 1 situates Turner's work in the history of landscape painting and in a wider survey of the moral power of art. He describes the picture as the noblest sea that Turner ever painted. It is, he says, a sunset on the Atlantic after a prolonged storm, painted as the storm is partially lulled, and the fire of the sunset falls along the trough of the sea, "dyeing it with an awful but glorious light, the intense and lurid splendour which burns like gold and bathes like blood." ${ }^{67}$ The review spends a lot of time talking about the sea, the quality of the light, and the painting of the water, but the language is saturated with moral symbolism, with "lurid" shadows, a furious swell and treacherous spaces of water, fearfully dyed in colours of blood. The night "gathers cold and low, advancing like the shadow of death upon the guilty ship as it labors amidst the lightning of the sea, its thin masts written upon the sky in lines of blood, girded with condemnation in that fearful hue which signs the sky with horror." ${ }^{68}$ Melanie Ulz argues that, like the other critics of the painting, Ruskin struggled to integrate the subject of the painting 
into his descriptive analysis of it. She points to the way he transferred the guilt from the people on board to the ship itself, focusing on the "aesthetic guilt of the objects," the guilty ship. ${ }^{69}$ In the review, Ruskin is constantly reflecting on the moral of the painting, on the guilt of the slavers and the "power, majesty and deathfulness of the open, deep, illimitable Sea."70 The painting first went on display in Johnston's private gallery and then at the inaugural exhibition of the new Metropolitan Museum of Art in New York in 1872, where viewers, influenced by Ruskin, saw it as "a miracle of light and color," and talked mainly about the extraordinary effect of sky and water, not about the victims or the subject-matter. ${ }^{71}$

According to McCoubrey, they "casually sanitised" the slaver in peril without discussing the people drowning in the foreground. ${ }^{72}$ Alice Hooper bought Slave Ship for $\$ 10,000$ in 1876 , the highest price ever paid in America for a European picture. It was put on display in 1877 at the Museum of Fine Arts in Boston, by itself in the Great Hall. Copies of Ruskin's review were copied and put on chairs in the hall, and viewers of the painting were asked to correspond with the Boston Evening Transcript about their reactions and opinions. The New York Times talks about visitors sitting in chairs arranged around the picture in a semi-circle, studying it from every angle, through their hands and through rolls of paper to try and get a "stereoscopic view" of the sky and the water, drawn to the gallery by the price paid for the painting, and by Ruskin's description of it. ${ }^{73}$

In Boston in 1877, George Inness described Turner's slave ship as “the most infernal piece of clap-trap ever painted." "There is nothing in it', he went on, 'it has as much to do with human affections and thought as a ghost." ${ }^{74}$ Hamerton attributed this kind of severity to a reaction to Ruskin's praise. Letters to the editor of the Boston Evening Transcript called the fishes simply ludicrous, and the bodies not realistic. The hands sticking out of the water were more like the footprints of giant, extinct birds, with no drawing, truth, feeling or expression. The chain cables meant to represent fetters were absurdly out of proportion, and truth had 
been utterly falsified by the painting. ${ }^{75}$ It was impossible for bodies to be eaten near to the surface, and the fish looked like gigantic perch. All the details were wrong: "The limb is that of a white woman, if such have ever been thrown overboard from slavers."76 The picture, these critical voices suggested, was a psychological picture of Turner's brain, made world famous by Ruskin whose eccentricity and dogmatism had "imposed on the world of art all that his phenomenal imagination saw, or thought it saw, in this painting."77 What would have happened, they asked, had there been no such description by Ruskin, and the painting had come to Boston on its merits? In response, others argued that the accuracy of the depiction of the fish, the shackles and the leg were unimportant in the face of the fantastic boldness of the painting as a work of the imagination, like A Midsummer Night's Dream or The Tempest. The painting could be corrected so that the fetters were at the bottom of the sea, and the fish under a fathom of water and "It might be more close to nature, but it would be like turning Puck into a telephone." 78

Others saw the painting as asking for more than admiration, as the embodiment of a giant protest, crying out against human oppression, throbbing with death and terror and blood, blazing with "the divine wrath of condemnation." Go down to your Art Museum, the writer of a letter to the editor exhorted the readers of the Boston Evening Transcript, "sit at the feet of this great canvas, and it shall preach to your souls a profounder sermon than the ears of your churches will hear!"79 The central white form in the painting appears "like an angel bursting forth with the right arm raised," descending in judgement from the top centre and condemning the massacre of the slaves below, "an entirely rational, if intentionally visionary, response to such a monstrous crime." ${ }^{80}$ The Slave Ship expressed the intuition of wrong, the sense that there is a God who judges the earth. Now that it belonged to a family of abolitionists, the painting became a sermon as it shifted between private and public spaces. Its 
audience began to try to define its social significance, and to make the link between fellowship with nature and the indignation in men's soul. ${ }^{81}$

This intense response to the message of the painting was part of an abolitionist reading that tried to "see the future in the present" through a specific lens, and was, in itself, a particular, political act of illumination. ${ }^{82}$ They mobilized the politics of the painting for the abolitionist cause by fitting it into their own constructions of time and space. For those who saw the angel and heard the sermon, the painting opened up the possibility of a linear conception of historical progress "in which the slavery of the past would be overcome and replaced by modern freedom." ${ }^{83}$ In this moralised reading of the guilty ship, the abolitionists were enabled to move towards recovery and recuperation, fabricating a particular history for themselves within which slavery could be treated as "a historical object that is completed or overcome, from which recovery would be possible." 84 The painting played its part in creating and solidifying a particular "affective relation to the past" for its white, indignant, forwardlooking audience, and that affective relation cemented a particular form of abolitionist politics. $^{85}$

This narrative of history and recovery was not available to the forced African migrants on board the ship, or for their descendants. For them, the painting is more like "the chronicle of death foretold." 86 The slave ship emerges as a site of 'black subjectivity and human terror' that contains, regulates and hides black humanity. ${ }^{87}$ Since the nineteenth century, responses to the Slave Ship have often continued to assume that Turner recorded the massacre on board the Zong. With a focus on black grief and death, there is a different quality to the light, a different sense of how the narrative unfolds, and of how we might inhabit historical time. Turner's painting, whether it is of the Zong, or of jettison, or of an angel (or of all of them at once), exemplifies "the sense of temporal entanglement, where the past, the present and the future, are not discrete and cut off from one another" that Hartman identifies 
as one of the elements of the afterlife of slavery. ${ }^{88}$ The slaves, unlike the white abolitionist audience, have no recourse to the "consolation of transcendence." 89 Instead, the painting is a reminder of the libidinal economy, the investment in violence that is, as Hartman argues, "everywhere apparent in the documents, statements and institutions that decide our knowledge of the past." 90 In the work of David Dabydeen and Fred D'Aguair, the Zong massacre lives on as "a haunting, troubling, foreign element within the present" that refuses to allow slavery to go away. ${ }^{91}$ D'Aguiar argues that what happened on board the Zong cannot be successfully mourned. It is "a voyage without beginning or end," full of deaths that cannot be undone, and death that has begun, but remains unfinished because it recurs. ${ }^{92}$

\section{Turner and slavery}

If slavery cannot be treated as a historical object, then we cannot privilege recovery and recuperation. This has political implications for us all. We need, as Lisa Lowe argues, to hesitate, to pause "mid-mourning." 93 In David Dabydeen's 1994 poem Turner, Turner is transformed into the Zong's captain, portrayed as a paedophile who preys on the captive young boys on the voyage, exercising both sexual and linguistic control. Dabydeen makes Turner complicit in the slave trade, and portrays the artist's visual representation of slaves as itself an act of sexual violation. Abigail Ward argues that Dabydeen's poem is about the ineffectiveness of visual art as a medium for exploring the past of slavery, and that the painting shows us Turner vandalising the past of slavery "in searching for his own fables of black powerlessness and victimhood." 94 It is here that we need to find the space to hesitate, and to allow for the sense of temporal entanglement. Turner's relationship to the past of slavery and the slave trade is an important part of the story, both for understanding the painting and for interpreting it in ways that can take us beyond a simple story of humanitarian triumph. 
Turner is generally taken to have been a liberal in his sympathies and in the causes he embraced, including parliamentary reform, freedom of expression, religious toleration and Greek independence, as well as abolition. During the 1820 s he was clearly in sympathy with the Whig opponents of the slave trade, but in 1805 he invested in the Dry Sugar Work pen in St Catherine's, Jamaica. This was an estate of around 1500 acres close to Spanish Town in the business of raising cattle for the local market. The investment scheme was designed to pay off the mortgage on the land, buy enough slaves to run the property, and remit the profits to subscribers in the form of life annuities. The scheme was a tontine, in which the value of the survivors' annuities increased each time one of the original subscribers (or nominees) died. Sam Smiles' research has revealed evidence that Turner nominated himself for the scheme, and bought a $£ 100$ share in his own name, enrolling as a subscriber at the age of thirty-one, expecting to recoup his initial outlay over seven years and then to make a profit.

As Smiles argues, Turner must have known that he was investing in a project that relied on slave labour. The printed proposals for the tontine mention that "a large gang of Negroes" needed to be purchased, bought as stock and treated as assets: "Negroes always greatly increase in Value, after they have been some time in the Island, so as to double the Amount of their first Price, after allowing any casual Loss by Death." 95 The tontine subscribers in 1805 were investing in slavery just as the abolition campaign against the slave trade was about to win, the facts were well known, and public opinion was shifting against it. Smiles points out that most abolitionists believed that ending the slave trade was sufficient, and that removing the possibility of resupply would ensure that existing slaves on plantations would be better treated. Many people were in favour of gradual, not immediate, abolition and the climate of gradual reform may have made the slave pens "the acceptable form of slave labour," far removed from what happened on board the Zong. ${ }^{96}$ So, there is Turner in the archive, dealing in this most doubtful species of property, subscribing to "the account books 
that identified [the enslaved Africans] as units of value, the invoices that claimed them as property, and the banal chronicles that stripped them of human features." ${ }^{\prime 97} \mathrm{He}$ is part of the "material record of dehumanization." 98

There is, Frost argues, among critics a consensus that Turner occludes the dying slaves. Ward identifies a "tradition of reading Turner's painting which fails to see the jettisoned slaves." 99 In Ruskin's account, we see the slaves relegated to a footnote, tossed overboard again, as Dabydeen puts it. Ruskin's footnote at the end of his critique of the painting reads: "She is a slaver, throwing her slaves overboard. The near sea is encumbered with corpses." ${ }^{100}$ There is some dispute among art historians about why this appears in a footnote. Jan Marsh argues that Ruskin assumed that his metropolitan audience would understand what the subject of the painting was, and he added a footnote when he realised that not all his readers would. ${ }^{101}$

Leo Costello, on the other hand, thinks that viewers of Turner's painting would have been surprised by the "very close and visceral presence" of the black woman, who is neither object nor subject, and at the edge of invisibility, about to be obscured by the storm. ${ }^{102}$ Turner's woman is fragmented and dismembered, provoking laughter, but she also carries with her some sense of resistance, a refusal to be buried, a terror of drowning and of the return of the dead, "a memory of terror and violence that will not be vanquished." 103 At the very edge of the painting, her humanity is made questionable by her fragmentation, and she appears as "the constitutive outside" that serves to enable humanitarianism. She is different from the white female convicts depicted in Turner's 1835 unfinished painting, A Disaster at Sea, who are not severed and fragmented, but holding, mourning and encircling their children, and from the victims in Shipwreck in 1805 who are depicted fully clothed, with visible faces, engaged in a process of struggle and rescue. Instead in her suffering, we can see the "violent shuttling" between object and subject status and "the morbid spectacle of 
severing." ${ }^{104}$ Her humanity has been documented and brought to light through abolitionism, and at the same time she is placed beyond the limits of what can be recognized as human. ${ }^{105}$ She keeps returning us to the question that Frank B. Wilderson asks of film, of how to tell the story of a sentient being whose story can neither be recognised nor incorporated into Human civil society. ${ }^{106}$

In his discussion of the Rwandan genocide Achille Mbembe points out that massacres reduce bodies to "simple relics of an unburied pain, empty, meaningless corporealities, strange deposits plunged into cruel stupor," but argues that what is striking is the tension between this emptiness and "their stubborn will to mean, to signify something." 107 This tension seems to me to be at the heart of Turner's painting, keeping before our eyes "the morbid spectacle of severing" and forcing us to confront what it means to be human, and how to live in the wake of the Zong and of the Slave Ship. ${ }^{108}$ For the viewer-as-abolitionist, the drowning slaves mark out the terrain of good and evil, and give us both moral authority and the "pleasure of flinching." ${ }^{109}$ For the viewer-as-slave, the drowning bodies, their groans and cries, are a reminder that intimacy with death continues to determine black existence, that, as Hartman puts it, the "hold continues to shape how we live," but also that there is resistance in that refusal to sink, to vanish out of sight, and in the memory of those captives who made the noble resolution to leap after their companions. ${ }^{110}$ Has the floating woman in the foreground found an edge, at the corner of the canvas, "beyond or before which true living unfolds?"111

The exchange between the viewer and the imagination of the artist is much more comfortable if we position the painting as about the Zong. It allows us to sentimentalize the suffering, to use other people's pain to believe something about ourselves. ${ }^{112}$ Simon Schama argues that this is the greatest British picture of the nineteenth century because it has both moral power and poetic vision, one articulated through the other. It attacks you in the gut, Schama says. Turner has drowned you in this moment and drenched you in his bloody light. 
It is, for Schama, a scene of martyrdom for the victims of the Zong, depicting retribution and judgement, but also a scene of vindication and of sin redeemed because of the patch of clearing blue sky on the right hand side. ${ }^{113}$ Turner's "ocean of light" is about redemption, a particular moment of illumination. McCoubrey, too, emphasises the role of hope in the painting - the burst of light at the centre, the clear patch of blue sky, the floating shackles that defy the laws of nature, the broken fetters, the upraised hands and the water turned to blood. In this "apocalyptic context" the sea is giving up its dead, rising in judgment and calling down vengeance on the murderers' heads. In this deeply abolitionist interpretation of the painting, it really does become all about hope and transformation, and, for Schama, about freedom. It is a kind of triumphal reading, bringing the events on board the Zong crashing up against the achievement of abolition and forcing us to make the link between the two. It feels much less stable and secure as an exchange if we look at the slaver as post-abolition ghost ship, still haunting the world after it is supposed to have been put to death.

\section{Modern Slavery: Pasts and presents}

The prevailing discourses of $\mathrm{m} \underset{\underline{\underline{\underline{P}}}}{\mathrm{P}}$ I slavery and new abolitionism look back at the history of the Middle Passage, the slave trade and the plantation, and draw lessons about the efficacy and virtue of abolitionism, and of antislavery activism more generally. They observe parallels between the British dominance of the seas in the nineteenth century and the current dominance of the US in allowing them both to "force other countries to get serious about prosecuting cases of slavery." ${ }^{114}$ For Jean Allain and Kevin Bales, the slavery of the past is a story of endings, "a story to be proud of, a story of progress." ${ }^{115}$ The danger is that it is also a story to be minimised and pushed into the past when the advocates of the new abolitionism claim that there are "more people in slavery today than at any time in human history." 116 
The estimated number of people in slavery today is presented as more than double the total number taken from Africa during the transatlantic slave trade. This then feeds into a story about the "alarming resurgence" of a phenomenon that we are supposed to understand has been relegated to the past. ${ }^{117}$ This idea of resurgence is linked to the claim that there is something new about Modern Slavery. It involves no legal ownership, high profits for the slave holders and a surplus of disposable slaves. Free the Slaves explain that: "Modern slaves are not considered investments worth maintaining. In the nineteenth century it was difficult to capture slaves and transport them to the United States. But today, when someone in slavery gets sick or injured, they are simply dumped or killed." ${ }^{118}$ For the new abolitionists, this disposability is the real evil of the new slavery, and what distinguishes it from the paternalism of old slavery. The focus on this rupture between the past and present means that such accounts do not see the victims of the Zong who were drowned and killed exactly because they were investments.

Having established that there are more slaves in the world today than at any other time in human history, and that modern slaves are distinguished from the slaves of the nineteenth century by being cheap and disposable, the Free the Slaves website goes to explain that "you are connected to slavery, and you can cure it." Their rhetoric connects the past to the present in very specific ways, through the story of antislavery activism: "There was a time when slavery was legal, and people considered it morally acceptably [sic] and economically essential. The battle to build a global consensus that slavery is unjust and unneeded has been won. Now we need to finish the job by freeing those still trapped in bondage."119 In 2016, a Christian anti-trafficking organisation, ZOE International, told visitors to its website that history is full of triumphant victories over unspeakable atrocities, specifically American slavery and the Holocaust. They then went on to frame human trafficking as the unspeakable horror for the younger generation to tackle. They may have missed the chance to 
battle against the injustice of transatlantic slavery or the holocaust, "But this time we are alive. Today we have the chance to do something about it." ${ }^{\prime 20}$ This, essentially, is the attraction of the story of the Zong, the sense that we would all be Granville Sharp or Thomas Clarkson (never the jettisoned cargo, and never Captain Collingwood, or even Turner with his tontine), and we would react with empathetic tears, witnessing the terrible story unfold and then doing something about it. The Zong distils the wrongs and injustices of slavery into a single moment of disposability, and then gives the new abolitionists Granville Sharp as a witness in the court, meticulously writing down every single piece of evidence, working tirelessly to try and bring murder charges against those who had carried out the massacre, and making sure that the details of the killings "dropped on the desk of the Prime Minister, the Chancellor of the Exchequer and the most powerful men in the Admiralty," ensuring that they could not claim ignorance of what had happened on board the ship. ${ }^{121}$ The discourse of new slavery is, in many of its manifestations, all about turning spectators into witnesses and inserting them into this story of abolition and humanitarian triumph. They do not hesitate, or see the face above the water, or struggle with how to inhabit historical time, but rush towards recovery. The old slavery, with its complicated injuries of racism and empire, is deliberately forgotten or covered over so that activists can concentrate on the scourge of modern slavery, hidden in our nail bars, and flowing into our offices, homes and schools. ${ }^{122}$

\section{Conclusion}

In trying to bring the painting back into history, we need to stay in the space of discomfort and hesitation and to be constantly questioning recovery, recognizing the present as "both aftermath and continuity." 123 The task, as Susan Sontag argues is to set aside the sympathy we extend to others "for a reflection on how our privileges are located on the same map as their suffering." 124 As viewers, we need to recognise that the painting does not release us 
from witnessing the violent shuttling between subject and object, or reassure us of our humanitarianism.

Turner's own involvement in slavery, and his refusal to look at the painting when it was on display in Ruskin's house, should remind us that this is a complex and contradictory painting, about seeing and not-seeing, guilt and complicity and death, and not straightforwardly about abolition. Its black subjects are both hidden and on display, seeable and unseeable, absent and present, both on and off the ship. ${ }^{125}$ We need to bring capital, property and race back into the picture, along with the resistance and humanity of the African captives. The painting shows us the interplay of past and present and future, the temporal entanglement, and Turner's “deeply sceptical vision of history and of the possibility of adequately representing it." 126

It is best, Costello argues, not to take the picture as a literal description of either the Zong or of jettison, but as deliberately making reference to both, so that "Turner's multiple time references $[\ldots]$ create a complex, diachronic history of British involvement in the slave trade," denying linear progression and forcing the two events into the same space, oscillating between time periods. ${ }^{127}$ The point, as Hartman argues in a different context, is not to conflate the two moments, "but to think about the constellation formed by them." 128 In viewing the painting, it is up to us to refuse the seductive pull of our own humanitarianism, the reductions and simplifications, the myths and narratives of abolitionism which risk framing victims as exceptions, locating them outside our shared humanity, and legitimising violent interventions. ${ }^{129}$

I want to go further than Costello in arguing that both slavery and the painting play with history in ways that go beyond bringing two separate events together. Turner was painting something like what Dennis Childs calls a "history of the present," and it should remind us of the persistent connections between racism and the global economy, of the 
complex history of terror, dispossession and rupture that underpins it, and of how politically important it is for us all to acknowledge where the past is still present. ${ }^{130}$ If it is a painting of jettison and the misdirected grasp of philanthropy, then it is casting the state as having the power to injure, and un-fixing the identity of the perpetrator. If it is painted from the perspective of Turner's present, then it is about more than demonizing the epoch of the slave trade and the Zong and preaching a sermon about transcendence, apology and reparation. ${ }^{131}$ If that is the case, then it can be read as a painting not about revenge and punishment, but about power and emancipation. We need to be careful about how we do this, and to hesitate and be doubtful about whether we can turn the painting into a picture of survival and achievement as well as suffering. How should we mobilize the politics of the painting?

There is a risk that this interpretation of the picture with a focus on its multiple frames, the complexity of complicity and as a history of the present only works if we are looking at the painting as spectators positioned outside the frame. From there, where we are not seen, "white presumptions of identitylessness" can remain intact. ${ }^{132}$ The painting is about temporal entanglement and an affective relation to the past, but both the entanglement and the relation are racialized in significant ways. Even if we give up on the redemptive narrative of humanitarian triumph and linear progress, we are still positioned as white in looking at the painting from outside the frame, "in the fertile ground of anxiety and ambivalence." 133 To avoid a moralized and de-politicized reading of the painting, we need to bring to it a critique of capitalist property relations that can ground a demand for reparations. We need to build a politics that can "grapple with the ways the past is lived" and reckon with the afterlives of slavery, not just in the unparalleled wickedness of the Zong, but also in the tensions of empire and of philanthropy. ${ }^{134}$ We can use Turner's painting to think about a complicated present that is still structured by the legacies of racial slavery and the uneven distribution of the category of the human. ${ }^{135}$ That means not losing sight of the reverberations of the hold, ${ }^{136}$ not 
relegating the drowning, floating bodies to a footnote, but recognising and protesting the continuing "deathfulness of the sea" in its many guises.

\section{Notes}

${ }^{1}$ Lambert, "Sierra Leone," 127.

${ }^{2}$ Hall, "Breaking Bread with History," 23.

${ }^{3}$ Beutin, "Black Suffering," 28.

${ }^{4}$ The Slave Trade Regulation Act of 1788, known as Dolben's Act, set limits on the number of shipboard slaves per ton that could be carried, and on how tightly packed the slaves could be, reducing the ratio from 6 to 5 men per 3 tons. For more on the Act, see James LoGerfo, "Sir William Dolben and "The Cause of Humanity"."

${ }^{5}$ Walvin, The Zong, 92. For further discussion and accounts of the Zong, see the special issue of the Journal of Legal History 28, no. 3 (2007). For the problems inherent in presenting an account of what happened, and the Zong's place in the struggle over competing theories of knowledge and the representation of slavery, see Ian Baucom's analysis in Specters of the Atlantic.

${ }^{6}$ Clarkson, History of the Slave-Trade, 78.

${ }^{7}$ Rupprecht, “Excessive Memories,” 14.

${ }^{8}$ Armstrong, Logic of Slavery, 168.

${ }^{9}$ Arvind, “Though it Shocks One Very Much,” 116.

${ }^{10}$ Ibid., 119.

${ }^{11}$ Hoare, Memoirs of Granville Sharp, xiii.

${ }^{12}$ Ibid., xx.

${ }^{13}$ Ibid., xx. 
${ }^{14}$ Ibid., xxi.

${ }^{15}$ Armstrong, "Slavery, Insurance and Sacrifice," 176.

${ }^{16}$ Hoare Memoirs of Granville Sharp, 242.

${ }^{17}$ Clarkson, History of the Slave-Trade, 78; Walvin, The Zong, 196.

${ }^{18}$ Clarkson, History of the Slave-Trade, 79.

${ }^{19}$ Rupprecht, "Excessive Memories,” 14.

${ }^{20}$ Baucom, Specters of the Atlantic, 92.

${ }^{21}$ Ibid., 132.

${ }^{22}$ Ibid., 135.

${ }^{23}$ Rupprecht, “A Limited Sort of Property,” 266. She talks about 29 March 2007 when a replica of the Zong sailed up the Thames escorted by a heavily armed naval frigate, HMS Northumberland. The replica ship carried an ethnically diverse Christian choir singing hymns of thanksgiving, and an exhibition about slavery in its hold, while the Northumberland had on board another exhibition, this time about the Navy's heroic role in stamping out the slave trade. As Rupprecht says, this was the might of the military, church and state coming together to celebrate their historic roles in abolition, and a reflection of how the past gets memorialised through trauma and guilt.

${ }^{24}$ Crowther, Critical Aesthetics, 106; Alei “As if we were present," 234.

${ }^{25}$ Baucom, Specters of the Atlantic, 288.

${ }^{26}$ Ibid., 289.

${ }^{27}$ Razack, "Stealing the Pain of Others," 386.

${ }^{28}$ Baucom, Specters of the Atlantic, 292.

${ }^{29}$ Razack, "Stealing the Pain of Others," 380.

${ }^{30}$ Hall, Civilising Subjects, 159. 
${ }^{31}$ Albert Boime argues that it is certain that Turner knew this book because "his rendering of the shackles seems to be dependent on a plate from it." It is true that the shackles in the painting look very like the shackles in Clarkson's book, but they also look like shackles in many other books, and they are the only visual clue to link the History to the painting.

32 Boime, "Turner's Slave Ship," 34.

${ }^{33}$ Lindsay, $J M W$ Turner, 190.

${ }^{34}$ Collett, McDougall, and Thomas, "Tracking the Literature of Tropical Weather," 3-4.

${ }^{35}$ Boime, "Turner's Slave Ship," 40.

${ }^{36}$ Ibid., 42.

${ }^{37}$ Frost, "The Guilty Ship,” 375-376; Abigail Ward reads the painting as a portrait of "black victimage," designed to absent black radicals from history: "Words are all I have left of my eyes."

${ }^{38}$ Frost, "The Guilty Ship," 376; For further discussion of the 1840 anti-slavery context, see Hall, Civilising Subjects.

${ }^{39}$ McCoubrey, “Turner's Slave Ship.”

${ }^{40}$ Pearson, "Waterwitch."

${ }^{41}$ Law, “Abolitionism and Imperialism,” 156.

${ }^{42}$ Christopher, "Looking forward from the deck," 23.

${ }^{43}$ Barcia and Kesidou, "Innovation and entrepreneurship," 553-554.

${ }^{44}$ Pearson, “Waterwitch,” 100.

${ }^{45}$ Burroughs, "Eyes on the Prize."

${ }^{46}$ Ibid., 100.

${ }^{47}$ Christopher, "Looking forward from the deck," 26.

${ }^{48}$ McCoubrey, “Turner's Slave Ship,” 325.

${ }^{49}$ Burroughs, "Eyes on the Prize," 102. 
${ }^{50}$ Spears, The American Slave-Trade, 144. There are further descriptions of the human cost of jettison in the Edinburgh Journal of 1844, where the Reverend Hill describes the bodies that would not sink, but floated "the face above the water, close to the vessel, and sometimes striking against the side," 153.

${ }^{51}$ Walvin, The Zong, 201.

${ }^{52}$ McCoubrey, “Turner’s Slave Ship,” 327.

${ }^{53}$ Ibid., 328.

${ }^{54}$ McKittrick, Demonic Spaces, xi.

${ }^{55}$ Costello, J. M. W. Turner, 206.

${ }^{56}$ McCoubrey, “Turner's Slave Ship,” 325.

${ }^{57}$ Butlin and Joll, The Paintings of J.M.W. Turner, 237.

${ }^{58}$ Wood, Blind Memory, 49.

${ }^{59}$ Boime, "Turner's Slave Ship," 42; Walvin, The Zong, 8.

${ }^{60}$ Ulz, "The Guilty Ship,” 142.

${ }^{61}$ Wood, Blind Memory, 50.

${ }^{62}$ Gravendyk, "Intertextual absences,” 163.

${ }^{63}$ Frost, "The Guilty Ship," 373; Ward, "Words are all I have left of my eyes," 48.

${ }^{64}$ Frost, "The Guilty Ship,” 382.

${ }^{65}$ Butlin and Joll, Paintings of J.M.W. Turner.

${ }^{66}$ Scott, “America’s first public Turner,” 72.

${ }^{67}$ Ruskin, Modern Painters, 376.

${ }^{68}$ Ibid., 377.

${ }^{69}$ Ulz, "The Guilty Ship,” 137.

${ }^{70}$ Ruskin, Modern Painters, 378.

${ }^{71}$ McCoubrey, “Turner's Slave Ship,” 349. 
72 Ibid., 349.

${ }^{73}$ This description of the first public viewings comes from Scott, "America's first public Turner," 74.

${ }^{74}$ Hamerton, The Life of JMW Turner, 19.

75 The painting was the subject of a series of Letters to the Editor of the Boston Evening Transcript at the end of March / beginning of April 1877. Boston Evening Transcript. 5 April 1877.

${ }^{76}$ Boston Evening Transcript. 5 April 1877.

${ }^{77}$ Boston Evening Transcript. 7 April 1877.

${ }^{78}$ Boston Evening Transcript. 23 March 1877.

${ }^{79}$ Boston Evening Transcript. 27 March 1877.

${ }^{80}$ Livesley, "The Later Life of Turner," 29.

${ }^{81}$ Walker, "From Private Sermon to Public Masterpiece."

${ }^{82}$ Lorde, The Master's Tools, 1.

${ }^{83}$ Lowe, "History Hesitant," 95.

${ }^{84}$ Ibid., 86.

${ }^{85}$ Hartman, "The Dead Book Revisited," 210.

${ }^{86}$ Ibid., 208.

${ }^{87}$ McKittrick, Demonic Spaces, xi.

${ }^{88}$ Hartman, On working with archives, 2.

${ }^{89}$ Sexton, “Afro-Pessimism." Sexton is quoting from Bryan Wagner.

${ }^{90}$ Hartman, "Venus in Two Acts," 5.

${ }^{91}$ Craps, "Learning to Live with Ghosts," 469.

92 Ibid., 472.

93 Lowe, "History Hesitant," 98. Craps, "Learning to Live with Ghosts." 
${ }^{94}$ Ward, "Words are all I have left of my eyes," 54.

${ }^{95}$ Smiles, "Turner and the Slave Trade," 48. The scheme was probably recommended to Turner by one of his patrons, some of whom owed their wealth to sugar plantations and the slave trade in the $1790 \mathrm{~s}$, and he turned up to the meeting in person to sign the agreement. ${ }^{96}$ Smiles, "Turner and the Slave Trade," 51.

${ }^{97}$ Hartman, "Venus in Two Acts," 3.

${ }^{98}$ Lowe, "History Hesitant," 87.

${ }^{99}$ Ward, "Words are all I have left of my eyes," 48.

${ }^{100}$ Ruskin, Modern Painters, 377.

${ }^{101}$ Marsh, "Ruskin and Turner's Slavers," 51.

${ }^{102}$ Costello, J. M. W. Turner, 225

${ }^{103}$ Ibid., 227.

${ }^{104}$ Bouchard, "Daring to Look," 114-115.

${ }^{105}$ Ibid., 117.

106 Sexton, "Afro-Pessimism"

${ }^{107}$ Mbembe, "Necropolitics," 35.

${ }^{108}$ Sharpe, In the Wake.

${ }^{109}$ Razack, "Stealing the Pain of Others," 378, 389.

${ }^{110}$ Hartman, "Dead Book,” 208.

${ }^{111}$ Sexton, "Afro-Pessimism."

${ }^{112}$ Razack, "Stealing the Pain of Others," 389.

${ }^{113}$ Schama, The Power of Art.

${ }^{114}$ Allain and Bales, "Slavery and its Definition," 502.

115 Ibid., 502.

${ }^{116}$ Hogenboom, “A tipping point?” 
${ }^{117}$ Free the Slaves.

${ }^{118}$ Free the Slaves

${ }^{119}$ Free the Slaves.

${ }^{120} \mathrm{ZOE}$.

${ }^{121}$ Walvin, The Zong, 167-168.

${ }^{122}$ Free the Slaves. For a much fuller critique of modern slavery discourse, see Brace,

Politics of Slavery.

${ }^{123}$ Lowe, "History Hesitant," 86.

${ }^{124}$ Razack, "Stealing the Pain of Others", 387.

${ }^{125}$ McKittrick, Demonic Spaces, xxx.

${ }^{126}$ Costello, J M W Turner, 204.

${ }^{127}$ Ibid., 207.

${ }^{128}$ Hartman, "Dead Book Revisited,” 208.

${ }^{129}$ Andrijasevic and Mai, "Editorial: Trafficking (in) representation."

${ }^{130}$ Childs, Slaves of the State.

${ }^{131}$ Balfour, "Reparations after identity politics."

132 Ibid., 795.

${ }^{133}$ Lee, Slavery and the Romantic Imagination, 2.

${ }^{134}$ Balfour, "Reparations," 802.

${ }^{135}$ Brace, Politics of Slavery, 223.

${ }^{136}$ Odysseos, "Poetic revolt."

\section{Acknowledgments}

A version of this paper was first presented to the Politics of Property specialist group meeting at the University of Nottingham in 2015 . Very many thanks to the members of that group for 
their responses, and in particular to Anita Rupprecht for all her help, comments and encouragement since then. Research for this paper included a visit to the archives of the Museum of Fine Arts in Boston in August 2018, made possible by the University of Leicester, where Julia Welch's help and hospitality were invaluable. For useful discussion and comments on the paper, many thanks to the members of the New History Lab at the University of Leicester, the BISA Ethics and World Politics Working Group (especially Louiza Odysseos) to Julia O'Connell Davidson, and to the anonymous reviewers for this journal.

\section{Disclosure Statement}

No potential conflict of interest was reported by the author.

\section{Notes on contributor}

Dr Laura Brace is Associate Professor in Political Theory at the University of Leicester. She is author of The Politics of Slavery (Edinburgh University Press, 2018) and editor (with Julia O’Connell Davidson) of Revisiting Slavery and Antislavery: Towards a Critical Analysis (Palgrave, 2018).

\section{Bibliography}

Alei, Paolo. “'As if we were present at the event itself”: The Representation of Violence in Raphael's and Titian's Heroic Painting," Artibus et Historiae 32, no. 64 (2011): 221224.

Allain, Jean and Kevin Bales. "Slavery and its Definition." In The Law and Slavery, edited by Jean Allain, 502-512. Leiden: Brill, 2015.

Andrijasevic, Rutvica, and Nicola Mai. "Editorial: Trafficking (in) representation: 
Understanding the Recurring Appeal of Victimhood and Slavery in Neoliberal Times.” Anti-Trafficking Review 7 (2016): 1-10.

Armstrong, Tim. "Slavery, Insurance and Sacrifice in the Black Atlantic.” In Sea Changes: Historicizing the Ocean, edited by K. Bernhard, 167-185. London: Routledge, 2004. Armstrong, Tim. The Logic of Slavery: Debt, Technology, and Pain in American Literature. Cambridge: Cambridge University Press, 2012.

Arvind, T. T. “"Though it Shocks One Very Much': Formalism and Pragmatism in the Zong and Bancoult." Oxford Journal of Legal Studies 32, no. 1 (2012): 113-151.

Balfour, Lawrie. "Reparations after identity politics.” Political Theory 33, no. 6 (2005): 786811.

Barcia, Manuel and Effie Kesidou. "Innovation and Entrepreneurship as Strategies for Success among Cuban-based Firms in the Late Years of the Transatlantic Slave Trade." Business History 60, no. 4 (2018): 542-561.

Baucom, Ian. Specters of the Atlantic. Durham, NC: Duke University Press, 2005.

Beutin, Lyndsey P. "Black Suffering for/from Anti-trafficking Advocacy." Anti-Trafficking Review 9, (2017): 14-30.

Boime, Albert. “Turner's Slave Ship: The Victims of Empire.” Turner Studies 10, no. 1 (1990): 34-43.

Bouchard, Danielle. “Daring to Look: Women without 'Faces' and Humanitarian Resentment." Feminist Formations 29, no. 3 (2017): 110-131.

Brace, Laura. The Politics of Slavery. Edinburgh: Edinburgh University Press, 2018.

Burroughs, Robert. "Eyes on the Prize: Journeys in Slave Ships Taken as Prizes by the Royal Navy." Slavery and Abolition 31, no. 1 (2010): 99-115.

Butlin, Martin, and Evelyn Joll. The Paintings of J.M.W. Turner. New Haven and London: Yale University Press, 1984. 
Childs, Dennis. Slaves of the State: Black Incarceration from Chain Gangs to the Penitentiary. Minneapolis: University of Minnesota Press, 2015.

Christopher, Emma. "Looking forward from the deck." Atlantic Studies: Global Currents 7, no. 1 (2010): 23-26.

Clarkson, Thomas. The History of the Rise, progress, and Accomplishment of the Abolition of the African Slave-Trade by the British Parliament. New York: John S. Taylor, 1836 (1808).

Collett, Anne. "Tracking the Literature of Tropical Weather." In Tracking the Literature of Tropical Weather: Typhoons, Hurricanes, and Cyclones, edited by Anne Collett, Russell McDougall and Susan Thomas, 1-25. London: Palgrave Macmillan, 2017.

Costello, Leo. J. M. W. Turner and the Subject of History. Farnham: Ashgate, 2012.

Craps, Stef. "Learning to Live with Ghosts: Postcolonial Haunting and Mid-Mourning in David Dabydeen's 'Turner' and Fred D'Aguiar's 'Feeding the Ghosts'.' Callaloo 33, no. 2 (2010): 467-475.

Crowther, Paul. Critical Aesthetics and Postmodernism. Oxford: Oxford University Press, 1996.

Emery, M. L. Modernism, the Visual and Caribbean Literature. Cambridge: Cambridge University Press, 2007.

Free the Slaves. Accessed 6 July 2018. https://www.freetheslaves.net/about-slavery/slaverytoday/.

Global Estimates of Modern Slavery. 2017. Accessed 9 July 2018. https://www.alliance87.org/2017ge/\#!section=0.

Gravendyk, Hilary. “Intertextual absences: 'Turner' and Turner.” The Comparatist 35 (May 2011): 161-169.

Hall, Catherine. Civilising Subjects: Metropole and Colony in the English Imagination 1830- 
1867. Cambridge: Polity, 2002.

Hall, Stuart. "Breaking Bread with History: CLR James and the Black Jacobins.” History Workshop Journal 46 (Autumn 1998): 17-32.

Hamerton, P. G. The Life of JMW Turner, R.A. London: Seeley, Jackson and Halliday, 1879. Hartman, Saidiya, interview by Thora Siemsen. "On working with archives.” Creative Independent (18 April 2018): 1-5. https://thecreativeindependent.com/people/saidiyahartman-on-working-with-archives/. Accessed 1 February 2019.

Hartman, Saidiya. “The Dead Book Revisited.” History of the Present 6, no 2 (2016): 208215

Hartman, Saidiya. "Venus in Two Acts." Small Axe 12, no. 2 (2008): 1-14

Hogenboom, Melissa. “A tipping point in the fight against slavery?” BBC News Magazine (19 October 2012). https://www.bbc.co.uk/news/magazine-19831913. Accessed 1 February 2019.

Lambert, David. "Sierra Leone, and Other Sites in the War of Representation over Slavery." History Workshop Journal 64, (Autumn 2007): 103-132.

Law, Robin. "Abolitionism and Imperialism: International Law and the British Suppression of the Atlantic Slave Trade." In Abolitionism and Imperialism in Britain, Africa, and the Atlantic, edited D. R. Peterson, 150-174. Columbus: Ohio University Press, 2010. Lee, Debbie. Slavery and the Romantic Imagination. Philadelphia: University of Pennsylvania Press, 2002.

Lindsay, Jack. J. M. W. Turner: His Life and Work. London: Cory, Adams and Mackay, 1966.

Livesley, Brian. “The Later Life of Turner: Body and Mind.” In Late Turner: Painting Set Free, edited by David Blayney Brown, Amy Concannon, and Sam Smiles, 25-32. London: Tate Publishing, 2014. 
LoGerfo, James W. "Sir William Dolben and "The Cause of Humanity": The Passage of the Slave Trade Regulation Act of 1788." Eighteenth Century Studies 6, no. 4 (1973): 431451.

Lorde, Audre. The Master's Tools Will Never Dismantle The Master's House. London: Penguin, 2018.

Lowe, Lisa. "History Hesitant." Social Text 33, no. 4 [125] (2015): 85-107.

Marsh, Jan. "Ruskin and Turner's Slavers: Patriotic, Political and Pictorial Issues.” Visual Culture in Britain 2, no 1 (2001): 47-63.

Mbembe, Achille, and Lisa Meintjes. "Necropolitics.” Public Culture 15, no. 1 (2003): 1140.

McCoubrey, John. “Turner's Slave Ship: Abolition, Ruskin and 'reception'.” Word and Image: A Journal of Verbal/Visual Enquiry 14, no. 4 (1998): 319-353.

McKittrick, Katherine. Demonic Grounds: Black Women and the Cartographies of Struggle. Minneapolis: University of Minnesota Press, 2006.

O'Connell Davidson, Julia. “Editorial: The Presence of the Past: Lessons of history for antitrafficking work." Anti-Trafficking Review 9 (2017): 1-12.

Odysseos, Louiza. "Poetic revolt, critical insurgency and historical apprenticeship in the 'afterlives of slavery'.” Millennium Conference, LSE, London, 27-28 October 2018.

Pearson, Andrew. "Waterwitch: A Warship, its Voyage and its Crew in the Era of AntiSlavery." Atlantic Studies: Global Currents 13, no. 1 (2016): 99-124.

Peterson, D. Abolitionism and Imperialism in Britain, Africa, and the Atlantic. Columbus: Ohio University Press, 2010.

Razack, Sherene. "Stealing the Pain of Others: Reflections on Canadian Humanitarian Responses." The Review of Education, Pedagogy, and Cultural Studies 29, no. 4 (2007): 375-394. 
Rupprecht, Anita. "A Limited Sort of Property: History, Memory and the Slave Ship Zong." Slavery and Abolition 29, no. 2, (2008): 265-277.

Ruskin, John. Modern Painters. New York: J. Wiley, 1848.

Schama, Simon. The Power of Art (2006). https://www.awesomestories.com/asset/view/137260. Accessed 15 March 2015.

Scott, Nancy. “America's First Public Turner: How Ruskin Sold 'The Slave Ship' to New York." The British Art Journal 10, no. 3 (2009): 69-77.

Sexton, Jared. “Afro-Pessimism: The Unclear Word.” Rhizomes: Cultural Studies in Emerging Knowledge 29 (2016). DOI 10.20415/rhiz/029.e02

Sharpe, Christina. In the Wake: On Blackness and Being. Durham NC: Duke University Press, 2016.

Smiles, Sam. "Turner and the Slave Trade: Speculation and Representation, 1805-1840." The British Art Journal 8, no. 3 (2007): 47-54.

Spears, John R. The American Slave-Trade: An Account of its Origin, Growth and Suppression. New York: Charles Scribner's Sons, 1900.

Ulz, Melanie. "The Guilty Ship: Memory and Cultural Denial in a Post-Abolitionist Society." In Slavery in Art and Literature: Approaches to Trauma, Memory and Visuality, edited by Birgit Haehnel, 125-146. Berlin: Frank and Timme, 2013.

Walker, Andrew. "From Private Sermon to Public Masterpiece: J.M.W. Turner's" The Slave Ship" in Boston, 1876-1899." Journal of the Museum of Fine Arts 6 (1994): 5-13.

Walvin, James. The Zong: A Massacre, the Law and the End of Slavery. New Haven, CT: Yale University Press, 2011.

Ward, Abigail. “'Words are all I have left of my eyes': Blinded by the Past in J.M.W. Turner's Slavers Throwing Overboard the Dead and Dying and David Dabydeen's ‘Turner'.” Journal of Commonwealth Literature 42, no. 1 (2007): 47-58. 
Wheeler, Roxanne. The Complexion of Race: Categories of Difference in Eighteenth-Century British Culture. Philadelphia: University of Pennsylvania Press, 2000.

Wood, Marcus. Blind Memory. Manchester: Manchester University Press, 2000.

Woods, Tryon. 2013. "Surrogate Selves: Notes on Anti-Trafficking and Anti-Blackness." Social Identities 19, no. 1 (2013): 120-134.

ZOE. Accessed 13 January 2017. goZOE.org: http://www.gozoe.org/what-is-humantrafficking/. 